Journal of Law \& Social Studies (JLSS)

Volume 3, Issue 2, pp 153-158

www.advancelrf.org

\title{
Corporate Governance Regulations and Practices under COVID-19 Crisis: Time to Rethink
}

\author{
Dr. Muhammad Ishtiaq \\ Assistant Professor, \\ Lyallpur Business School, Government College University, Faisalabad. \\ Email: mishtiaq@gcuf.edu.pk \\ Hina Mushtaq \\ Ph.D Scholar, \\ Lyallpur Business School, Government College University, Faisalabad.
}

\begin{abstract}
The COVID-19 has brought the challenge of survival for all the companies around the globe. This pandemic totally changed the procedures of managing and governing the firms with the help of regulations of the state. The said disaster has also hit the existence of the major companies in different sectors of the economy. Consequently, it has drawn the attention of all the practitioners of the Corporate Governance along with the policy makers of the economy. The focus of this article is to see the utility and practicability of different regulations and practices of the corporate governance to cope with the current emerging challenges of COVID-19 in corporate sector. Furthermore, the current study takes some valuable insights from the leading business journal articles and find the key mechanisms of the corporate governance, which help the companies to deal with the recent crisis. These mechanisms could be effective for the different business units during this dilemma of COVID-19. This review intends to change the management philosophy of the different companies. Furthermore, this study aims to provide them with the latest mechanisms of corporate governance, which are helping the companies for their successful progression of business affairs in this tough time of Corona Virus. These mechanisms include presence of risk management committee, more attention to the stakeholders, family ownership, and block holders. This paper concludes that all the above said mechanisms of corporate governance are very helpful during the crisis of COVID-19. The study highlights that this pandemic has affected the governance mechanisms of al the establishments, therefore firms should be prepared for such crisis in future by paying attention to the different corporate governance mechanisms. The study recommends that certain practices of the corporate governance are very helpful in coping the challenges posed by the pandemic of COVID-19.
\end{abstract}

Keywords: COVID-19, Block holders, Corporate Governance

\section{Introduction}

A crisis can be defined as any event that become a turning point for better or worse. Crisis can be categorized into two classes: the events controlled by the management of the company and the events, which are beyond the control of the management. The crisis can result in the loss of investment opportunities, deterioration of assets, revenues, profitability, and loss of customers, bad debts, impaired loans and decrease in the wealth of shareholders. Under such situation, the management of the establishments can introduce various reforms, for instance changing the rules, regulations, opening or closing of communication with the staff or by introducing the new reforms and regulations for managing the operations of the company (Marcus \& Goodman, 1991). Authors also argues that for maximizing the profits of the shareholders and for achieving the long-term effectiveness, the establishments must develop the competencies to cope not only with their day-to-day events but for the uncertain events of the future as well such as crisis (Smart \& Vertinsky, 1984).

The COVID-19 pandemic has obstructed the global economy. It is projected that the global economy is much worse than the Financial Crises during the 2008- 09 as a result of the said pandemic. The global financial crisis appeared in 2008, which causes the liquidity crisis for the major companies of the world. Consequently, the policy makers must deliver the relief packages for the major financial institutions around the globe. These crisis results in the collapse of the top banks and financial institutions of the world which include Freddie Mac, Northern Rock, and Lehman Brothers (Wiggins, Piontek \& Metrick, 2019). The whole world is paralyzed again with the pandemic of COVID-19 after twelve years. This crisis is very different from the global financial crisis. The global financial crisis affected the top 
companies of the world, and its spillover effect was experienced by the global financial system, but the impact of COVID-19 affects the health system of the whole world. The pandemic has far-reaching effects on the global economies. This virus affected the daily life of the people as well. Earlier health outbreaks, for instance mouth disease, Severe Acute respiratory syndrome, Swine flu, bird flu, and other related disease has an impact on some economies.

The pandemic of COVID-19 has affected the lives and economic activities of the whole world. This virus was originally spreads from the Wuhan, the city of China in December 2019. Then, it spreads to the other countries of the world. The States of all the countries are taking different proactive measures for controlling the spread of this virus in their countries (Wenzel, Stanske \& Lieberman, 2020). The Government impose shutdowns, lockdowns and prohibition of events and activities. All these measures were taken to control the spread of Coronavirus, but it has profound ill effects on the economic conditions of the whole world. The whole words see a decline in the values of their assets (Zhang, Hu, \& Ji, 2020). For mitigating these, side effects of COVID-19, the Government of different countries have introduced different fiscal and monetary policies. This virus challenged the survival of various companies and start raising the concerns for the practices of corporate governance. This study aims to investigate that how the mechanism of the corporate governance can help the corporations to cope with the challenges of crisis of COVID-19.

The first purpose of this study is to review the different literature that provide insight of the different corporate governance practices, which the company uses during different crisis. The focus of this study is on the Asian financial crisis that how the corporations of Asia cope with the challenges of COVID-19. The main purpose of the study is to focus on the mechanism of corporate governance during this crisis. Secondly, the study will review the literature to find that how the practices of Corporate Governance can mitigate the effects of these crisis. Lastly, the study provides the implications by exploring the latest and useful practices of corporate governance.

Corporate governance is very important for the successful working of the organization. The different discipline across the world is relying on this practice. These are kind of control system, by which the owners of the corporation try to affect the control on the working of their board of directors. Dowell, Shackell, \& Stuart (2011) find that this is the way of maximizing the value of the shareholders in the corporation. This include both the internal and external monitoring by the shareholders himself. Studies have found that effective corporate governance mechanism help in increasing the performance, sales, customers base, liquidity, and survival of the companies (Aguilera, Florackis \& Kim, 2016; Michelberger, 2016; Khatib \& Nour, 2021).

The countries, which are having weak corporate governance mechanisms in their companies, they experiences decline in the performance of their establishment, which consequently resulting decrease in their net worth in these crises. The strong and effective mechanisms of the corporate governance is necessary for the survival of the firms in the time of crisis (Johnson et al., 2000). Furthermore, Lin et al. (2006) has found that the practices of corporate governance are different for the crisis because those practices, which are effective during the crisis are not affect in the normal conditions of the firm. On the contrary, the practices, which are effective in normal conditions, are not effective during the crisis. There, corporations need to alter the mechanism of corporate governance during the crisis of COVID -19.

Gelter \& Puaschunder (2020) examines its potential effect on corporate governance in comparison. To lead a big economy, a community first must achieve a stable political social balance. Three tendencies stand out: a need for resilience, the rise of nationalist policies in company law, and a growing focus on "stakeholder" concerns. To begin, businesses must become more resilient to the crisis and, as a result, more long-term oriented. Second, corporate governance is expected to have seen a rise of nationalism to ensure that foreign ownership and interconnected supply chains do not jeopardize national security. Third, current critiques of inequality, as well as increased awareness of climate change, may hasten the trend toward a broadening of corporate purpose to include "stockholders" and public policy matters.

Jebran \& Chen (2021) have examined the influence of corporate governance policies can assist companies in surviving the COVID-19 problem. The epidemic also has put the companies' viability in jeopardy, drawing the attention of governments and corporate governance practitioners all over the world. According to their analyses, firms may be susceptible to at least one of the identified governance mechanisms, but they may discover the utility and effectiveness of these governance practices in the COVID-19 situation. Mathew \& Sivaprasad (2020) have investigated the consequences of the COVID-19 issues on corporate governance practices. They have revealed that epidemics have an influence on corporate governance, and that firms must be ready for just any eventuality in the future by paying attention to business continuity plans in the event of natural disasters and epidemics. It concludes with policy suggestions that companies should adopt in principle to deal with epidemics of this amplitude. 
Patel, Patel \& Patel (2020) have looked at a variety of practical challenges and risks that corporations face, as well as the consequences and new relief measures that have been implemented in relation to Corporate Governance in India during the COVID-19 spread. Exploratory research is used to analyze and study the practical challenges and consequences that corporations confront when it comes to corporate governance. This study analyses have discovered that the COVID 19 pandemic has had a substantial commercial impact over the world.

In additional to previous study, Khatib \& Nour (2021) has examined how COVID-19 affects corporate governance characteristics and organizational performance. They found that board numbers don't matter in the uncertain time of the present situation, but board composition appears to be markedly boosting firm performance in the crises period compared to the prior year, in which it has an inverse correlation with firms' performance in both indicators. This study used a sample of 188 non-financial firms from the Marketplace for such decades 2019-2020. The impact of COVID-19 on the various financial markets of the world is studies by many authors. The COVID-19 has brought the challenging crisis for all the global economies. Not all the humankind experienced such a big crisis in magnitude in their recent time. This virus disturbs the economies of the entire world and economists predict the world recession due to ill effects of this virus. This virus brings the challenges for the performance of the establishments. These challenges are from the internal and external environment. Under such a situation, there is no set design for any company, which ensure that the companies will continue to perform well in future during this crisis period (Jebran \& Chen, 2021)

\section{Mechanism of Corporate Governance during the Crisis of COVID-19}

This study provides some important mechanisms of Corporate Governance, which are very effective during the crisis of COVID-19 for the success of various corporations.

\section{More attention to Stakeholders of the corporations}

The primacy of the shareholders is the main stone of the agency-based models of the corporate governance. The crisis increases the importance of stakeholders for the companies because these cannot survive alone over the time. The companies struggled during the crisis of COVID-19 because of the lost customers. Some other firms experience the reduced workforce of their productive and important employees. The exit of employees causes the disturbance in their supply chain and production as well. These problems cause the issue of insufficient capital, increased debt and decrease in the interest earning ability of the firms. It became crucial for the establishment to update their board of directors regarding the situation of the important group of stakeholders. The board of the corporation has declared the health and safety issues of the corporation on their top priority. The companies are putting their stakeholders on the top for managing their operations during this tough time of crisis. The COVID-19 has disturbed the mental health of the employees during this pandemic, which is affecting their productivity as well.

Chawla et al. (2020) studies that the limited separation between private spheres and work life lead towards the many difficulties and problems in unplugging from the work demands of the employers. As per Stakeholder theory, the organization should take care of its multiple constituencies for making it effective and successful; otherwise, it can cause many problems for it. Some employees feel isolated during this pandemic, and it has affected their productivity as well. They have found that remote working has increase the risk of loneliness and feeling of lack of purpose among the employees during the COVID-19. Butterick \& Charlwood (2021) have found that if any external element affects any of the function of HRM then it would affect all the functions of the organization. The COVID-19 has affected all the functions of the company; therefore, there should be excellent communication between the manger and its remote working staff. They have discovered that for getting work done by the employees in the crisis of Corona, agility is required in the organization, and it is possible only if we treat them as a human being rather than like machines.

Carnevale \& Hatak (2020) have identified the challenges and opportunities that COVID-19 brings for the organizations and their functions. His study identifies the importance of integrating the various Human Resource Management functions during this pandemic for making the organizations effective. Donthu \& Gustafssson (2020) have found that COVID-19 is a sharp reminder for all the organizations. Maurer (2020) has identified that the organizations should choose the virtual hiring process of hiring during the pandemic of COVID-19. Elsafty \& Ragheb (2020) have highlighted that having a clear workplace planning set the expectation of the incoming employees and help the company in satisfying the needs of their stakeholders. They further have revealed that when the work environment is supportive and collaborative and fulfil the desires of the staff during the pandemic of COVID-19. It results in the increased productivity of the employees. 
During the crisis of COVID-19, Boards face the increased pressure from all their stakeholders, especially from employees of the company. They are increasing their voice, due to which to board will have to increase their monitoring process and include them in the decision-making process of the corporation. These stakeholders directly challenge the working of the companies, therefore, among all the pressure on the board, the pressure from the stakeholders especially from the employees is very important for the board. The board should take their employees seriously and manage them. The COVID-19 has badly affected the business world. It brings many challenges for the organizations, which need to be address on the priority basis. It affects the sales, working conditions, morale of the employees and increase the turnover ratio of the staff. The virus introduces the new trend of remote working in the companies, which create the feeling of loneliness in them. The employees are no more willing to come back to their offices. Therefore, much structured attention is required to be given to all the important stakeholder of the firm especially its employees, who are important for the working of the corporations.

\section{Risk Management Committees}

One of the most important mechanisms that is very effective during the Crisis of COVID-19 is the presence of risk management committee in the corporation (Jebran \& Chen 2021). The presence of this risk management committee relates to its independence (Yeh, Chung \& Liu, 2011). The studies have found the positive impact of independence of risk management committee on the revenues, assets value and performance of the firm during the period this crisis. The study suggest that the directors of the risk management committee should be independent because they can give independent reviews on the risk factors of the company during the period of this crisis.

\section{Family ownership}

The family firms perform well during the crisis of COVID-19. Family owners can help in retaining the resources of the firm, which are helpful for survival during the period of economic crisis (Baek, Kang \& Park, 2004; Boubakri, Guedhami \& Mishra, 2010). Secondly, the family firms absorb the economic shocks and help in the long-term survival of the firm. Jebran \& Chen 2021 have determined that there is a positive relationship between the family ownership and performance of the corporation during the crisis of COVID-19. These family firms manage their assets efficiently and invest the further capital, if necessary for the survival of the firm. These firms do not have to face the liquidity issues due to the lack of capital. They have enough cushion to cover the crisis of Corona virus.

\section{Block holders}

Block holders of the corporation hold the largest portion of the outstanding shares of the corporation. This allows them to exercise the much control on the director of the firm. These block holders exercise the direct control on the board of directors of the firm. They closely monitor their performance. The active monitoring and information acquisition by the block holders are very important for the survival and good performance of the firm during the crisis of COVID19. Grove et al. (2011) find the positive relationship between the presence of block holders inside the firms and performance of the corporation. These block holders can govern the management by exerting their control on the monitoring process of the firm (Bharath, Jayaraman, and Nagar, 2013). During the Asian crisis, these block holders are playing a positive role and help in increasing the performance of the corporations.

\section{Conclusion and Implications}

Based on the above-mentioned studies, it can be revealed that the current crisis of COVID-19 has triggered a kind of health crisis, due to which effective practices of corporate governance need to be revise because these practices would help the companies in mitigating their risk. The past experiences of the crisis provide the base for the establishments to revise their policies and corporate framework for mitigating the effects of crisis of COVID-19. The current study has reviewed the articles of the top journals of the world and collect the articles from different journal by searching the key word (for instance, crisis, failure, COVID-19, Corporate Governance, Liquidity issue, subprime). This study has focused on the mechanisms of the corporate governance, which are used during this time of crisis. The overall focus is to find the most efficient and effective practices which can help the establishment new rules or amendment the existing regulations for the smooth functioning of the business affairs in this tough time of crisis.

This study has several implications after examining a substantial body of existing literature focusing on the various corporate governance practices. This study reveals that the COVID-19 crisis has increased the importance of different stakeholders such as employees, customers, and suppliers. Consequently, companies should take their employees seriously and manage them for their survival the crisis of COVID-19. The current research also discovers effectiveness of risk management committees as an important valuable tool to deal with the existing crises. Furthermore, this study has concluded that risk management committees are required to be effective in crises based on their more 
independence. This study suggests that the family ownership has had an advantage during crises. The existing literature highlights that family firms are more flexible and effective against different natural disasters and economic crisis. Furthermore, it is also revealed from the relevant literature that family ownership in companies permits them to better credit access to cope with COVID-19 crises. Finally, it is also evident from literature that block holders have more effectiveness during crises to cope with crises.

\section{References}

Aguilera, R. V., Florackis, C., \& Kim, H. (2016). Advancing the corporate governance research agenda. Corporate Governance: An International Review, 24(3), 172-180.

Butterick, M., \& Charlwood, A. (2021). HRM and the COVID-19 pandemic: How can we stop making a bad situation worse? Human Resource Management Journal.

Baek, J. S., Kang, J. K., \& Park, K. S. (2004). Corporate governance and firm value: Evidence from the Korean financial crisis. Journal of Financial economics, 71(2), 265-313.

Bharath, S. T., Jayaraman, S., \& Nagar, V. (2013). Exit as governance: An empirical analysis. The Journal of Finance, 68(6), 2515-2547.

Boubakri, N., Guedhami, O., \& Mishra, D. (2010). Family control and the implied cost of equity: Evidence before and after the Asian financial crisis. Journal of International Business Studies, 41(3), 451-474.

Carnevale, J. B., \& Hatak, I. (2020). Employee adjustment and well-being in the era of COVID-19: Implications for human resource management. Journal of Business Research, 116, 183-187.'

Chawla, N., MacGowan, R. L., Gabriel, A. S., \& Podsakoff, N. P. (2020). Unplugging or staying connected? Examining the nature, antecedents, and consequences of profiles of daily recovery experiences. Journal of Applied Psychology, 105(1), 19.

Patel, C. D., Patel, N. K., \& Patel, N. K. (2020). COVID-19 and corporate governance (India): Practical issues, implications and new relief measures. COVID-19 and Corporate Governance (India): Practical Issues, Implications and New Relief Measures (September 11, 2020).

Donthu, N., \& Gustafsson, A. (2020). Effects of COVID-19 on business and research. Journal of business research, 117, 284-289.

Elsafty, A. S., \& Ragheb, M. (2020). The role of human resource management towards employee's retention during Covid-19 pandemic in medical supplies sector-Egypt. Business and Management Studies, 6(2), 5059-5059.

Gelter, M., \& Puaschunder, J. M. (2020). COVID-19 and comparative corporate governance. J. Corp. L., 46, 557.

Grove, H., Patelli, L., Victoravich, L. M., \& Xu, P. (2011). Corporate governance and performance in the wake of the financial crisis: Evidence from US commercial banks. Corporate Governance: An International Review, 19(5), 418-436.

Jebran, K., \& Chen, S. (2021). Can we learn lessons from the past? COVID-19 crisis and corporate governance responses. International Journal of Finance \& Economics.

Johnson, S., Boone, P., Breach, A., \& Friedman, E. (2000). Corporate governance in the Asian financial crisis. Journal of financial Economics, 58(1-2), 141-186.

Khatib, S. F., \& Nour, A. N. I. (2021). The impact of corporate governance on firm performance during the COVID19 pandemic: evidence from Malaysia. Journal of Asian Finance, Economics and Business, Forthcoming.

Lin, Z., Zhao, X., Ismail, K. M., \& Carley, K. M. (2006). Organizational design and restructuring in response to crises: Lessons from computational modeling and real-world cases. Organization Science, 17(5), 598-618.

Marcus, A. A., \& Goodman, R. S. (1991). Victims and shareholders: The dilemmas of presenting corporate policy during a crisis. Academy of management journal, 34(2), 281-305.

Mathew, S., \& Sivaprasad, S. (2020). Corporate governance practices in the context of the pandemic crisis. Available at SSRN 3590253. 
Michelberger, K. (2016). Corporate Governance effects on firm performance: a literature review. Regional Formation \& Development Studies, (20).

Smart, C., \& Vertinsky, I. (1984). Strategy and the environment: A study of corporate responses to crises. Strategic management journal, 5(3), 199-213.

Wiggins, R. Z., \& Metrick, A. (2019). The lehman brother's bankruptcy h: The global contagion. Journal of Financial Crises, 1(1), 172-199.

Yeh, Y.-H., Chung, H., \& Liu, C.-L. (2011). Committee independence and financial institution performance during the 2007-08 credit crunch: Evidence from a multi-country study. Corporate Governance: An International Review, 19(5), 437-458.

Zhang, D., Hu, M., \& Ji, Q. (2020). Financial markets under the global pandemic of COVID-19. Finance Research Letters, 36, 101528. 